\title{
Comment
}

\section{Pakistan, India and American Power}

\section{William J. Barnds}

One of the lessons that Vietnam was supposed to have taught all of us concerned the limits of American power-that we could not police the world, and that our influence on an intractable international system was quite modest. But recent events involving the subcontinent suggest that the illusion of American omnipotence dies hard, in Asia as well as in the United States.

When the upheaval in East Bengal began in March, the Nixon Administration, in line with its proclaimed doctrine, adopted a low profile. It halted most-though unfortunately not all-military shipments to Pakistan and made no new economic aid commitments. It worked through quiet diplomacy, neither publicly supporting nor denouncing Yahya Khan's resort to arms or India's covert support for the Bengali guerrillas. But when the war began, an administration supposedly attuned to hard-headed power considerations became emotionally caught up in the sinking cause of a united Pakistan. Did it really think that speeches and resolutions in the United Nations or a carrier task force steaming into the Bay of Bengal would enable the U.S. to counter India's clear preponderance of power in the subcontinent?

If the Administration's moral insensitivity and political unrealism have made its errors appallingly clear, there is a danger that the claims of those opposing it will be accepted without serious examination. News reports from India asserting that many Indians believe the United States could have forced a political settlement on Pakistan and thus have prevented war have now been given the official Indian stamp of approval. Mrs. Gandhi, writing to President Nixon, has stated: "War could have been avòided if the power, influence, and authority of all the states, and above all the United States, had got Sheikh Mujibar Rahman released."

But was Pakistan in fact so dependent on the United States that it could have forced Yahya Khan to release Mujib and grant East Bengal its independence? U.S. aid has been declining for several years, and Pakistan was obtaining nearly all of its arms elsewhere-chiefly from China. Once Yahya and his associates unleashed their reign of terror they were psychologically and politically trapped; freeing $\mathrm{Mu}$ $\mathrm{jib}$ and granting the demands of East Bengal would have undermined their entire policy and, more importantly, their base of support in West Pakistan. If Yahya had been either a weak man or a wise one, pressure or persuasion might have succeeded. Unfortunately, he was neither.
If Indians are inclined to blame the United States, many Americans, angered at their government's alienation of India, claim-in the words of the New York Times-that the "Nixon Administration practically drove India into the waiting arms of the Russians by its silence in the face of brutal repression in East Pakistan and by economic and military support it witlessly continued to extend to Pakistan. . ." But India's treaty with the Soviet Union was as much a response to the Nixon Administration's dramatic move to improve relations with China as it was to U.S. aid to Pakistan. New Delhi already possessed military power sufficient to deal with Pakistan: It wanted arms and protection against China and support in the U.N. in case war developed and China was tempted to intervene. U.S. opposition to Pakistan would have mitigated Indian fears of isolation but would not have abolished them. Unless the United States had been willing to forsake its new China policy, or supply India with arms, a closer MoscowNew Delhi tie was almost inevitable. A more sensible U.S. policy would have avoided the current animosity between Washington and New Delhi, but would not have altered the basic if unpalatable fact that the top priority of Asian nations is security and power, and they look most favorably on those who help them realize these ambitions.

There is little the United States can immediately do to alter the situation, for power and responsibility in the turbulent times ahead will rest in other hands. Indo-Soviet ties will remain close, but if held within limits need not threaten basic United States interests in the Asian subcontinent. Prime Minister Gandhi-now one of Asia's dominant figures-has no desire to be completely dependent on Moscow, and with Pakistan destroyed India's need for Soviet support diminishes. New Delhi's calm response to China's recent attacks indicates Mrs. Gandhi still wants to expand India's freedom of maneuver by a rapprochement with Peking. And New Delhi is likely in time to want a normalization and then an improvement of relations with the United States-provided we have, in the meantime, had the sense to limit our activities in the subcontinent to relief for the victims of war and upheaval, and have not tried to assuage Pakistan's sense of insecurity by renewing arms shipments or giving new assurances of support.

William J. Barnds is a Senior Research Fellow at the Council on Foreign Relations and author of a just published book, India, Pakistan and the Great Powers. 